\title{
Vênus em dois atos ${ }^{1}$
}

Venus in Two Acts

\section{Saidiya Hartman}

Professora de Letras e Literatura Comparada na Columbia University, autora de Scenes of Subjection: Terror, Slavery, and Self-Making in Nineteenth Century America (1997), Lose Your Mother: A Journey Along the Atlantic Slave Route (2007) e Wayward Lives, Beautiful Experiments: Intimate Histories of Social Upheaval (2019), este último vencedor do National Book Critics Circle Award. Ganhadora em 2019 do Prêmio MacArthur.

\section{Tradução:}

\section{Fernanda Silva e Sousa}

Doutoranda no Programa de Pós-Graduação em Teoria Literária e Literatura Comparada da Universidade de São Paulo

\section{Marcelo R. S. Ribeiro}

Professor de História e Teorias do Cinema e do Audiovisual na Faculdade de Comunicação da Universidade Federal da Bahia

\section{Revisão}

Kênia Freitas e Liv Sovik

\footnotetext{
1 Publicado originalmente como HARTMAN, Saidiya, "Venus in Two Acts,". In: Small Axe, Volume 12, no. 2, pp. 1-14. Copyright 2008, Small Axe, Inc. Todos os direitos reservados. Republicado com permisão da Duke University Press. www.dukeupress.edu. Acesso em: https://doi.org/10.1215/12-2-1. Esta tradução ao português será incluída em uma antologia de black studies, organizada por André Arias, Clara Barzaghi e Stella Paterniani, a ser lançado pela Crocodilo Edições e Bazar do Tempo em 2021.
} 


\section{RESUMO}

Este ensaio examina a ubíqua presença de Vênus no arquivo da escravidão atlântica e luta com a impossibilidade de descobrir qualquer coisa sobre ela que já não tenha sido afirmada. Como figura emblemática da mulher escravizada no mundo atlântico, Vênus evidencia a convergência do terror e do prazer na economia libidinal da escravidão, assim como a intimidade da História com o escândalo e o excesso de literatura. Ao escrever no limite do indizível e do desconhecido, o ensaio mimetiza a violência do arquivo e tenta repará-la ao descrever tão plenamente quanto possível as condições que determinam a aparição de Vênus e que ditam seu silêncio.

PALAVRAS-CHAVE: arquivo; narrativa; escravidão; violência; Vênus.

\section{ABSTRACT}

This essay examines the ubiquitous presence of Venus in the archive of Atlantic slavery and wrestles with the impossibility of discovering anything about her that hasn't already been stated. As an emblematic figure of the enslaved woman in the Atlantic world, Venus makes plain the convergence of terror and pleasure in the libidinal economy of slavery and, as well, the intimacy of history with the scandal and excess of literature. In writing at the limit of the unspeakable and the unknown, the essay mimes the violence of the archive and attempts to redress it by describing as fully as possible the conditions that determine the appearance of Venus and that dictate her silence.

KEYWORDS: archive; narrative; slavery; violence; Venus.

Nesta encarnação, ela aparece no arquivo da escravidão como uma garota morta nomeada em uma acusação judicial contra um capitão de navio negreiro julgado pelo assassinato de duas garotas negras. Mas nós poderíamos tê-la encontrado de modo igualmente fácil no livro de contabilidade de um navio, no registro de débitos; ou no diário de um feitor - "ontem à noite eu deitei com Dido no chão"; ou como uma companheira amorosa de cama com uma bolsa tão elástica "que conterá a maior coisa com a qual qualquer cavalheiro possa presenteá-la" na Harris's List of Covent Garden Ladies ${ }^{2}$; ou como a amante na narrativa de um soldado mercenário no Suriname; ou como uma proprietária de um bordel no relato de um viajante sobre as prostitutas de Barbados; ou como uma personagem

2 A Lista de Harris das Senhoras de Covent Garden, em tradução livre, foi impressa e publicada anualmente no formato de um almanaque entre 1757 e 1795 no distrito de Covent Garden, em Londres. A publicação reunia descrições físicas e especialidades sexuais de mais de uma centena de prostitutas que trabalhavam na cidade. [N.T.] 
menor em um romance pornográfico do século XIX. ${ }^{3}$ Variavelmente chamada de Harriot, Phibba, Sara, Joanna, Rachel, Linda e Sally, ela é encontrada em todo lugar no mundo atlântico. 0 entreposto de escravos, o oco do navio negreiro, a casa de pragas, o bordel, a jaula, o laboratório do cirurgião, a prisão, o canavial, a cozinha, o quarto do senhor de escravos acabam por se revelar exatamente o mesmo lugar e em todos eles ela é chamada de Vênus.

O que mais há para saber? Seu destino é o mesmo de qualquer outra Vênus Negra: ninguém lembrou do seu nome ou registrou as coisas que ela disse, ou observou que ela se recusou totalmente a dizer alguma coisa. ${ }^{4}$ A sua história, ${ }^{5}$ contada por uma testemunha falha, é extemporânea. Seriam necessários séculos para que lhe fosse permitido "provar sua língua". ${ }^{6}$

Eu poderia dizer, seguindo um filósofo famoso, que o que sabemos de Vênus em suas muitas formas equivale a "pouco mais do que um registro do seu encontro com o poder" e que isso fornece "um esboço insuficiente de sua existência"7. Um ato de acaso ou desastre produziu uma divergência ou uma aberração em relação ao curso esperado e usual de invisibilidade e a catapultou do subterrâneo para a superfície do discurso. Nós nos deparamos com ela em circunstâncias exorbitantes que não produzem nenhuma imagem da vida cotidiana, nenhum caminho para seus pensamentos, nenhum vislumbre da vulnerabilidade de seu rosto ou do que olhar para tal rosto poderia exigir. Nós só sabemos o que pode ser extrapolado a partir de uma análise do livro de

3 "Last night cum Dido." Feitor na Jamaica, Thomas Thistlewood relata em latim suas façanhas sexuais com mulheres escravizadas. "Cum sup terr" ("Eu fodi com ela no chão"). In: Douglas Hall, ed., In Miserable Slavery: Thomas Thistlewood in Jamaica 1750-1756 (Kingston: The Press University of the West Indies, 1998), 31. Samuel Derrick, Harris's List of Covent-Garden Ladies, or Man of Pleasure's Kalendar for the Year 1793 (London, 1793; reimpressão: Edinburgh: Paul Harris Publishing, 1982), 83. John Gabriel Stedman, Stedman's Surinam: Life in an Eighteenth-Century Slave Society, org. Richard Price e Sally Price (Baltimore: Johns Hopkins University Press, 1992).

4 Para um relato estendido do dilema de Vênus, ver o livro de Janelle Hobson, Venus in the Dark: Blackness and Beauty in Popular Culture (New York: Routledge, 2005).

${ }^{5}$ No decorrer do ensaio, Hartman utiliza variavelmente as palavras history e story. Optamos por distinguir entre esses termos, um denotando a história dos historiadores e outro, relatos, ficcionais ou não, estórias que se contam, pelo uso - hoje antiquado - do H maiúscula quando se trata da história maior, da historiografia. [N.T.]

${ }^{6}$ Ver M. NourbeSe Philip, She Tries Her Tongue, Her Silence Softly Breaks (London: The Women's Press, 1993).

7 Michel Foucault. A vida dos homens infames. In: Estratégia, poder-saber. Ditos e escritos IV. Tradução Vera Lucia Avellar Ribeiro. Rio de Janeiro: Forense Universitária, 2003, p. 207.

Dossiê Crise, Feminismo e Comunicação - https://revistaecopos.eco.ufri.br/ 
contabilidade ou emprestado do mundo de seus captores e senhores, e aplicado a ela. No entanto, precisa-se transformar o exorbitante em exemplar ou típico para que a vida dela forneça uma janela para as vidas das pessoas escravizadas em geral.

Não se pode perguntar "Quem é Vênus?", porque seria impossível responder a essa pergunta. Há centenas de milhares de outras garotas que compartilham as suas circunstâncias, e essas circunstâncias geraram poucas histórias. E as histórias que existem não são sobre elas, mas sobre a violência, o excesso, a falsidade e a razão que se apoderaram de suas vidas, transformaram-nas em mercadorias e cadáveres e identificaram-nas com nomes lançados como insultos e piadas grosseiras. 0 arquivo, nesse caso, é uma sentença de morte, um túmulo, uma exibição do corpo violado, um inventário de propriedade, um tratado médico sobre gonorréia, umas poucas linhas sobre a vida de uma prostituta, um asterisco na grande narrativa da História. Dado isso, “é sem dúvida impossível apreender [essas vidas] de novo em si mesmas, como se elas estivessem 'em um estado livre'”. ${ }^{8}$

\section{Fora do mundo e de volta}

Mas eu quero dizer mais do que isso. Eu quero fazer mais do que recontar a violência que depositou esses traços no arquivo. Eu quero contar uma história sobre duas garotas capazes de recuperar o que permanece adormecido - a aderência ou reivindicação de suas vidas no presente - sem cometer mais violência em meu próprio ato de narração. É uma história fundamentada na impossibilidade - de escutar o não dito, traduzir palavras mal interpretadas e remodelar vidas desfiguradas - e decidida a atingir um objetivo impossível: reparar a violência que produziu números, códigos e fragmentos de discurso, que é o mais próximo que nós chegamos a uma biografia da cativa e da escravizada.

Entretanto, como recuperar vidas emaranhadas com e impossíveis de diferenciar dos terríveis enunciados que as condenaram à morte, dos livros de contabilidade que as identificaram como unidades de valor, das faturas que as

\footnotetext{
${ }^{8}$ Ibid., p. 208.
}

Dossiê Crise, Feminismo e Comunicação - https://revistaecopos.eco.ufrj.br/ 
afirmaram como propriedades e das crônicas banais que as despojaram de características humanas? "Pode o choque de [tais] palavras", como Foucault escreve, "dar origem a um certo efeito de beleza misturado com terror?"9 Nós podemos, como NourbeSe Phillip sugere, "conjurar alguma coisa nova a partir da ausência dos africanos como humanos que está no coração do texto?"10 Se sim, quais são as feições dessa nova narrativa? Colocando de modo diferente, como se reescreve a crônica de uma morte prevista e antecipada como uma biografia coletiva de sujeitos mortos, como uma contra-História do humano, como prática da liberdade?

Como a narrativa pode encarnar a vida em palavras e, ao mesmo tempo, respeitar o que não podemos saber? Como alguém ouve os gemidos e gritos, as canções indecifráveis, o crepitar do fogo nos canaviais, os lamentos pelos mortos e os brados de vitória, e então atribui palavras a tudo isso? É possível construir um relato a partir do "locus da fala impossível" ou ressuscitar vidas a partir das ruínas? ${ }^{11}$ Pode a beleza fornecer um antídoto à desonra, e o amor uma maneira de "exumar gritos enterrados" e reanimar os mortos? ${ }^{12}$

Ou é a narração sua própria dádiva e seu próprio fim, isto é, tudo que é realizável quando a superação do passado e a redenção dos mortos não o são? E, de qualquer forma, o que as histórias tornam possível? Um jeito de viver no mundo no rescaldo da catástrofe e da devastação? Uma casa no mundo para o ser [self] mutilado e violado? ${ }^{13}$ Para quem - para nós ou para elas?

A escassez de narrativas africanas sobre o cativeiro e a escravização exacerba a pressão e a gravidade de tais questões. Não há uma única narrativa

\footnotetext{
9 Ibid., p. 206.

10 M. NourbeSe Philip, Zong! (Middletown: Wesleyan University Press, 2008).

11 Stephen Best, "The African Queen," ensaio não publicado.

12 Assia Djebar, Fantasia: An Algerian Calvacade, trans. Dorothy S. Blair (London: Heinneman, 1993).

13 Relendo o conto de Sa'adat Hasan Manto, "Khol Do," em que um pai reivindica o corpo violado de sua filha, Veena Das escreve: "Esse pai deseja que a sua filha viva mesmo que partes de seu corpo não possam fazer nada além de proclamar sua brutal violação... Ele cria através de sua enunciação ["Minha filha está viva - minha filha está viva"] um lar para o mutilado e violado eu de sua filha." Veena Das, Life and Words: Violence and the Descent into the Ordinary (Berkeley: University of California Press, 2007) 39, 47.
}

\section{Dossiê Crise, Feminismo e Comunicação - https://revistaecopos.eco.ufrj.br/


autobiográfica de uma mulher cativa que sobreviveu à Passagem do Meio ${ }^{14}$. Esse silêncio no arquivo, em combinação com a robustez do forte ou do entreposto de escravos, não como uma cela de detenção ou espaço de confinamento, mas como episteme, faz com que a historiografia do tráfico escravista, em sua maior parte, focalize assuntos quantitativos e questões de mercados e relações comerciais ${ }^{15}$. A perda dá origem ao anseio e, nessas circunstâncias, não seria exagerado considerar as histórias como uma forma de compensação ou mesmo como reparações, talvez o único tipo que nós iremos receber.

Como uma escritora comprometida em contar histórias, eu tenho me esforçado em representar as vidas dos sem nomes e dos esquecidos, em considerar a perda e respeitar os limites do que não pode ser conhecido. Para mim, narrar contra-Histórias da escravidão tem sido sempre inseparável da escrita de uma História do presente, ou seja, o projeto incompleto de liberdade e a vida precária do(a) ex-escravo(a) ${ }^{16}$, uma condição definida pela vulnerabilidade à morte prematura e a atos gratuitos de violência ${ }^{17}$. Conforme eu a entendo, uma História do presente luta para iluminar a intimidade da nossa experiência com as vidas dos mortos, para escrever nosso agora enquanto ele é interrompido por esse passado e para imaginar um estado livre, não como o tempo antes do cativeiro ou da escravidão, mas como o antecipado futuro dessa escrita.

14 Em inglês, essa travessia é comumente chamada de "Middle Passage", o comércio triangular de escravizados, que envolvia a África, as Américas e a Europa, e era realizado através do Oceano Atlântico, "a passagem do meio" entre os três continentes. [N.T.].

15 Stephanie Smallwood, Saltwater Slavery (Cambridge: Harvard University Press, 2007).

16 Em inglês, Hartman escreve: "the precarious life of the ex-slave", recorrendo a termos que não têm marcação de gênero gramatical. No decorrer do texto, definimos o gênero gramatical dos substantivos e adjetivos que traduzem o texto de Hartman de acordo com o contexto em que aparecem. Mais abaixo, por exemplo, quando Hartman se refere a "the dead", traduzimos simplesmente por "os mortos", sem marcar explicitamente a questão no próprio texto, embora ela deva ser considerada, já que se trata de mortos e mortas na história da escravidão. Em outro momento, quando a autora se refere a uma "cultural history of the captive", traduzimos como "história cultural do cativeiro", mas quando ela se refere às "lives of the captives", optamos por "vidas dos cativos e cativas", já que a expressão aponta para a concretude histórica de existências individuais, e Hartman está particularmente interessada no lugar histórico das mulheres. [N.T.]

17 Achille Mbembe, On the Postcolony (Berkeley: University of California Press, 2001), 173-74. Mbembe aborda a arbitrária e caprichosa natureza do poder colonizador "em retirar do mundo e matar o que já havia sido previamente decretado como nada, como uma figura vazia" (189).

Dossiê Crise, Feminismo e Comunicação - https://revistaecopos.eco.ufrj.br/ 
Essa escrita é pessoal porque essa História me engendrou, porque "o conhecimento do outro me marca"18, por causa da dor experimentada em meu encontro com os fragmentos do arquivo e por causa dos tipos de histórias que construí para fazer a ponte entre o passado e o presente e dramatizar a produção do nada - cômodos vazios, e silêncio, e vidas reduzidas ao descarte.

Quais são os tipos de histórias a serem contadas por e sobre aqueles e aquelas que vivem em tal relacionamento íntimo com a morte? Romances? Tragédias? Gritos que fazem seu caminho para a fala e a canção? Quais são os protocolos e limites que moldam as narrativas escritas como contra-História, uma aspiração que não é um profilático contra os riscos decorrentes ao reiterar discursos violentos e representar novamente rituais de tortura? Como se revisita a cena de sujeição sem replicar a gramática da violência? A “beleza terrível” que reside em tal cena é de algum modo semelhante a um remédio, como Fred Moten pareceria sugerir ${ }^{19} 0$ tipo de beleza terrível e de música terrível que ele discerne nos gritos de Tia Hester ${ }^{20}$ transformados nas canções da Great House Farm ${ }^{21}$ ou na fotografia da face destruída de Emmett Till22, e a "acuidade do olhar"23 que surge

18 Das, Life and Words, 17.

19 Fred Moten, In the Break (Minneapolis: University of Minnesota, 2003), 14-22, 198-200. 0 primeiro dos dois trechos citados aqui foi publicado em português sob o título "A resistência do objeto: o grito da Tia Hester". In: ECO-Pós, Vol. 23, No. 1 (2020). Disponível en: https://doi.org/10.29146/eco-pos.v23i1.27542.

20 Tia Hester era a tia de Frederick Douglass, ex-escravizado, orador e abolicionista afro-americano. Quando criança, viu sua tia ser espancada por um feitor a ponto de ficar completamente ensanguentada. Esse episódio, que aparece no primeiro capítulo de sua Narrativa da Vida, foi um dos relatos pelos quais caracteriza a escravidão. Moten e Hartman discutem, em seus textos, a oportunidade e problemas de reiterar e, portanto, reencenar a tortura da Tia Hester [N.T.]

${ }^{21}$ A Great House Farm era a sede das plantações em que Douglass nasceu e trabalhou como escravo. Ele relata a ida mensal de escravizados para essa sede para retirar os mantimentos. Descreve seu canto como algo que expressava, para quem ouvisse, os horrores da escravidão. Moten usa esse trecho de Douglass para esboçar uma posição que ele compartilha com Hartman: que a escravidão não pode ser entendida somente pelas torturas e a opressão que impôs e que esses autores relutam em re-representar, mas pela beleza criada pelas pessoas escravizadas. 0 texto de Moten lida exatamente com a contradição, paradoxo e dilema que esse fato constitui diante de quem observa e ouve. A gravação de "Protest", de Max Roach e Abbey Lincoln, citada por Moten, mostra o que ele está argumentando. [N.T.]

22 Em agosto de 1955, quando Emmett Till, um garoto afro-americano de 14 anos criado em Chicago, visitava parentes em uma pequena cidade de Mississipi, foi acusado de assobiar para uma mulher branca. $\mathrm{O}$ marido e cunhado dessa mulher o torturam, mutilaram e mataram com um tiro na cabeça alguns dias depois. A mãe de Emmett, Mamie Till Mobley, decidiu, como uma forma de denunciar a violência racista, deixar o caixão de seu filho aberto no velório, expondo seu rosto desfigurado e destruído para que o mundo pudesse ver o que ela jamais conseguiria descrever. Os

Dossiê Crise, Feminismo e Comunicação - https://revistaecopos.eco.ufrj.br/ 
da disposição de olhar para o caixão aberto. As possibilidades superam os perigos de olhar (de novo)?

Se "ler o arquivo é entrar em um necrotério, permitindo uma visualização final e autorizando um último vislumbre de pessoas prestes a desaparecer no porão de escravos" 24 , então com qual fim alguém abre o caixão e olha para a face da morte? Por que arriscar a contaminação envolvida na reafirmação das maldições, obscenidades, colunas de perdas e ganhos e medidas de valor pelas quais as vidas cativas eram inscritas e extintas? Por que sujeitar os mortos a novos perigos e a uma segunda ordem de violência? Ou são as palavras do mercador a ponte para os mortos ou os túmulos escriturários em que eles esperam por nós? Tais preocupações sobre a ética da representação histórica explicam, em parte, os "dois atos" do título. Eu preciso revisitar e revisar meu próprio relato anterior sobre a morte de Vênus em "O Livro Morto"25; e, também, os dois atos anunciam o inevitável retorno de Vênus, tanto como "fantasma" ["haint"] ${ }^{26}$, ou seja, o que assombra o presente, quanto como vida descartável. 0 relato do mercador sobre mortalidade evidencia a inevitabilidade da repetição: Melancolia, desinteria, idem, idem. Em vez do esforço desperdiçado de traçar uma linha sobre "menina magra" ou escrever um "recusar menino", o livro de contabilidade introduz outra morte por meio dessa taquigrafia. E nos devolve os mortos "na própria forma em que foram expulsos do mundo". ${ }^{27}$

assassinos foram processados no mês seguinte e um júri de brancos os considerou não culpados. Meses depois, confessaram o crime em uma matéria de revista de grande circulação. A brutalidade do assassinato foi tanta e o gesto da mãe tão certeira que essa morte foi creditada, como a de George Floyd está sendo agora, com o início de uma nova fase da luta contra o racismo nos Estados Unidos. [N.T.]

${ }^{23}$ Elaine Scarry, On Beauty and Being Just (Princeton: Princeton University Press, 2001), 14. 0 texto discute como o olhar se altera, com a percepção de beleza que antes não era vista, ou com a perda da percepção de beleza em um objeto antes admirado. A "acuidade do olhar" é necessária para perceber essas alterações. [N.T.]

${ }^{24}$ Saidiya Hartman, Lose Your Mother (New York: Farrar, Straus, and Giroux, 2007), 17.

25 Ibid., 136-53.

26 "Haint", substantivo originado do verbo em inglês "haunt", é um fantasma raivoso que assombra casas. A palavra provavelmente tem origem entre os Gullah Geechee, descendentes de escravizados que viviam na Carolina do Sul, nos Estados Unidos. [N.T.]

27 Michel Foucault. A vida dos homens infames. In: Estratégia, poder-saber. Ditos e escritos IV. Tradução Vera Lucia Avellar Ribeiro. Rio de Janeiro: Forense Universitária, 2003, p. 207. 


\section{0 caixão aberto, o escândalo do arquuivo}

Escândalo e excesso inundam o arquivo: os números brutos das contas de mortalidade, a sonegação estratégica e a desonestidade do registro do capitão, as cartas floridas e sentimentais despachadas de portos de escravos por mercadores com saudades de casa, as histórias encantatórias de violência chocante escritas por abolicionistas, os relatos fascinados de testemunhas oculares feitos por soldados mercenários ansiosos para divulgar "o que a decência os proíbe de revelar" e os rituais de tortura, os espancamentos, enforcamentos e amputações consagradas como lei. 0 investimento libidinal na violência é aparente em toda parte nos documentos, declarações e instituições que decidem nosso conhecimento do passado. 0 que foi dito e o que pode ser dito sobre Vênus tem como certo o tráfego entre fato, fantasia, desejo e violência.

Confirmações disso são abundantes. Vamos começar com James Barbot, o capitão da Fragata de Albion, que atestou a coincidência dos prazeres proporcionados no espaço da morte. Era difícil exercer contenção sexual no navio negreiro, confessou Barbot, porque as "jovens donzelas vivazes, cheias de alegria e bom humor, proporcionavam uma abundância de recreação."28

Falconbridge ${ }^{29}$ endossa isso, ampliando o deslizamento entre vítimas e namoradinhas, atos de amor e excessos brutais: "A bordo de alguns navios, os marinheiros comuns podem ter relações sexuais com as mulheres negras cujo consentimento podem obter. E sabe-se que alguns deles levaram a inconstância de suas amantes tão a sério a ponto de pularem ao mar e se afogarem". Somente Olaudah Equiano ${ }^{30}$ retrata a violência habitual do navio negreiro sem recorrer à linguagem do romance: "Era quase uma prática comum entre nossos empregados e outros brancos cometer violentas depredações da castidade das escravas... Eu tenho conhecimento de que nossos oficiais cometiam esses atos da maneira mais

28 "A Voyage in the Albion Frigate," in Churchill's Voyages, vol. 5 (1732), republicado em George Francis Dow, Slave Ships and Slaving (New York: Dow, 2002), 81.

${ }^{29}$ Alexander Falconbridge (1760-1791) foi um cirurgião britânico que participou de quatro viagens em navios negreiros entre 1780 e 1787. [N.T.]

30 Olaudah Equiano (1745-1797) foi um ex-escravizado, abolicionista, marinheiro e escritor nigeriano, que escreveu uma autobiografia chamada The Interesting Narrative of the Life of Olaudah Equiano, publicada em 1789. [N.T.] 
vergonhosa, para a desgraça não apenas de cristãos, mas também dos homens. Eu tenho conhecimento até mesmo de que eles satisfazem sua paixão brutal com meninas de menos de dez anos de idade; e alguns deles praticaram essas abominações com tal escandaloso excesso que um dos nossos capitães dispensou o oficial e outros por causa disso" (ênfase minha). ${ }^{31}$

A situação piora na plantação. Os estupros em série e as punições com excrementos perpetrados por Thomas Thistlewood ${ }^{32}$ oferecem um relato vívido dos prazeres extorquidos pela destruição e pela degradação da vida e, ao mesmo tempo, iluminam a dificuldade de recuperar vidas escravizadas das forças aniquiladoras de uma descrição como essa: "Dei nele uma chicotada moderada, conservei ele bem em salmoura, suco de limão e pimenta, fiz Hector cagar em sua boca, imediatamente colocar uma mordaça nela enquanto estava cheia \& o fiz usálo por 4 ou 5 horas." 33 Enquanto o registro diário de tais abusos constitui, sem dúvidas, uma História da escravidão, a tarefa mais difícil é exumar as vidas enterradas sob essa prosa, ou em vez disso aceitar que Phibba e Dido existem apenas dentro dos confins dessas palavras, e que esta é a maneira como eles entram na História. 0 sonho é liberar essas vidas das obscenas descrições que primeiro as apresentaram para nós. É fácil demais odiar um homem como Thistlewood; o que é mais difícil é reconhecer como nossa herança as frases latinas brutais que se derramam nas páginas dos seus diários.

Ao entrar no arquivo da escravidão, o inimaginável assume a forma da prática cotidiana, que nunca deixamos de esquecer enquanto olhamos boquiabertas os rostos sombrios e torsos desnudos de Delia, Drana, Renty e Jack, ou nos horrorizamos diante do corpo mutilado de Anarcha, ou admiramos uma Diana nua, tão linda que até "o traje mais esplêndido não pode lhe acrescentar

${ }^{31}$ Alexander Falconbridge, An Account of the Slave Trade on the Coast of Africa (London: J. Phillips, 1780), 23-24. Olaudah Equiano, The Interesting Narrative (1789; reprint, New York: Penguin, 1995), 104.

32 Thomas Thistlewood ( 1721-1786) foi um feitor e proprietário britânico de terras e de escravizados na Jamaica, que escreveu 37 diários sobre sua vida e a escravidão, detalhando o tratamento destinado aos cativos. Seus textos são considerados um importante documento histórico sobre o sistema escravista na Jamaica e o tráfico atlântico. [N.T.]

${ }^{33}$ Hall, In Miserable Slavery, 72. 
qualquer elegância". ${ }^{34}$ Outros aparecem sob a pressão e a incitação do discurso: uma flagelada e uma hotentote ${ }^{35}$. Uma vadia carrancuda. Uma preta morta. Uma puta sifilítica.

Falas inapropriadas, expressões obscenas e comandos arriscados dão origem aos personagens com os quais nós nos deparamos no arquivo. Dada a condição em que os encontramos, a única certeza é que os perderemos novamente, que eles irão expirar ou escapar da nossa compreensão ou desmoronar sob a pressão da investigação. Esse é o único fato sobre Vênus do qual podemos ter certeza. Então, é possível reiterar seu nome e contar uma história sobre matéria degradada e vida desonrada que não encanta e excita, mas, em vez disso, se aventura em direção a outro modo de escrita?

Se não é mais suficiente expor o escândalo, então como seria possível gerar um conjunto diferente de descrições a partir desse arquivo? Imaginar o que poderia ter sido? Visualizar um estado livre a partir dessa ordem de afirmações? Os perigos envolvidos nessa tentativa não podem ser colocados entre parênteses ou evitados por causa da inevitabilidade da reprodução dessas cenas de violência, que definem o estado da negritude e a vida da(o) ex-escrava(o). Pelo contrário, esses perigos estão situados no coração do meu trabalho, tanto nas histórias que escolhi contar como naquelas que evitei.

Aqui eu gostaria de retornar a uma história que preferi não contar ou não conseguia contar em Lose Your Mother ${ }^{36}$. É uma história sobre Vênus, a outra garota que morreu a bordo do Recovery e a quem fiz apenas uma breve referência.

34 Stedman, Stedman's Surinam, 248. Delia, Drana, Renty e Jack eram sujeitos fotográficos do estudo de Louis Aggasiz sobre poligênese; Aranchna era uma das onze escravizadas usadas como experimentos por Morton Sims, o fundador da ginecologia. Ver Harriet Washington, Medical Apartheid: The Dark History of Medical Experimentation from Colonial Times to the Present (New York: Harlem Moon, 2006).

350 termo hotentote corresponde à designação colonial do povo khoisan, grupo étnico do Sudoeste africano. Entre 1810 e sua morte em 1815, Sara Baartman, frequentemente chamada pelo diminutivo em holandês Saartjie, foi uma das mulheres khoisan expostas em diversas cidades europeias, em casas de espetáculo de variedades e outros contextos metropolitanos, além de ter sido objeto de estudos pseudocientíficos racistas, em função das características de seu corpo. Ela se tornou conhecida como Vênus Hotentote. [N.T.]

36 Publicado em 2007, Lose Your Mother: A Journey Along the Atlantic Slave Route é um livro que transita entre história, romance e autobiografia. Nele, Harman retoma o tráfico atlântico a partir de sua viagem a Gana, quando buscou reconstituir, através de fragmentos e indícios da captura de 


\section{O segundo ato}

Duas garotas morreram a bordo do Recovery. 0 capitão, John Kimber, foi indiciado por ter "espancado e torturado uma escrava, de modo criminoso, cruel e com malícia premeditada, de maneira a causar a morte dela: e ele foi novamente indiciado por ter causado a morte de outra escrava." 37

Em 7 de junho de 1792, o Sr. Pigot, advogado do prisioneiro, berrou o nome Vênus ao interrogar o cirurgião Thomas Dowling, uma das duas testemunhas da tripulação do navio que atestaram que tinham visto o Capitão John Kimber assassinar uma garota negra. De acordo com o depoimento do cirurgião, o capitão a açoitou repetidamente com um chicote e "sucessivamente por vários dias, muito severamente", causando sua morte. ${ }^{38}$

Vênus não era aquela garota negra, mas outra que tinha morrido nas mãos do capitão e que foi mencionada brevemente durante o julgamento. Pigot questionou o cirurgião sobre ela:

Pergunta: Não havia uma menina comprada do [traficante] Jackamachree, que estava no mesmo estado que a menina sobre quem temos falado?

Resposta: Eu não sei.

Pergunta: Não havia uma menina com o nome Vênus?

Resposta: Havia.

Pergunta: Ela não estava no mesmo estado?

Resposta: Não que eu saiba. ${ }^{39}$

"Havia uma outra menina a bordo do Recovery ... a quem chamaram Vênus, e ela também tinha pústulas." 40

africanos, a sua genealogia, perdida inevitavelmente como uma das consequências da escravidão. A perda dessa origem é, na obra, comparada à perda da mãe, sugerindo que tanto ela quanto pessoas escravizadas são órfãs e não têm um lugar no mundo. [N.T.]

37 The Trial of Captain John Kimber for the Murder of Two Female Negro Slaves, on Board the Recovery, African Slave Ship (1792), 2.

38 The Whole of the Proceedings and Trial of Captain John Kimber, for the Murder of a Negro Girl (1792), 14-15.

39 Ibid., 25.

40 Trial of Captain Kimber for the Murder of a Negro Girl (1792), 19. 
Quando o capitão foi absolvido do assassinato da primeira garota, ele também foi considerado inocente da segunda acusação. "Como não havia [mais] evidência para sustentar o segundo indiciamento do que a que sustentava o primeiro, o júri também absolveu o prisioneiro em relação a ele."41

Essas foram as únicas palavras faladas sobre Vênus durante o julgamento.

Escrevi duas frases sobre Vênus em "O Livro Morto”, mascarando meu próprio silêncio atrás do de Wilberforce. Sobre ele, digo: "Ele escolheu não falar de Vênus, a outra garota morta. 0 apelido carinhoso autorizou a devassidão e o fez soar agradável"42.

Decidi não escrever sobre Vênus por razões diferentes daquelas que atribuí a ele. Ao contrário, eu temia o que poderia inventar, e teria sido um romance.

Se eu pudesse ter invocado mais do que um nome em uma acusação, se eu pudesse ter imaginado Vênus falando em sua própria voz, se eu pudesse ter detalhado as pequenas memórias banidas do livro de contabilidade, então teria sido possível que eu representasse a amizade que poderia ter florescido entre duas garotas assustadas e solitárias. Companheiras de navio. Então Vênus poderia ter assistido sua amiga moribunda, sussurrado conforto em seu ouvido, a embalado com promessas, a acalmado com "logo, logo" e desejado a ela um bom regresso.

Imagine as duas: as relíquias de duas garotas, uma acalentando a outra, inocentes espoliadas; um marinheiro avistou as duas e mais tarde disse que eram amigas. Duas garotas sem mundo encontraram um país nos braços uma da outra. Ao lado da derrota e do terror, haveria isso também: o vislumbre de beleza, o instante de possibilidade.

${ }^{41}$ Trial of Captain John Kimber for the Murder of Two Female Negro Slaves, 36; The Trial of Captain Kimber for the Supposed Murder of an African Girl, at the Admiralty Sessions (1792), 43.

42 Hartman, Lose Your Mother, 143.

Dossiê Crise, Feminismo e Comunicação - https://revistaecopos.eco.ufri.br/ 
A perda de histórias aguça a fome por elas. Então é tentador preencher as lacunas e oferecer fechamento onde não há nenhum. Criar um espaço para o luto onde ele é proibido. Fabricar uma testemunha para uma morte não muito notada.

Em um estado livre, teria sido possível, para as garotas, atentar para a morte de uma amiga e derramarem lágrimas pela perda, mas um navio negreiro não permitia o luto e, quando detectado, os instrumentos de tortura eram empregados para erradicá-lo. Mas o consolo dessa visão - uma vida reconhecida e lamentada no abraço de duas garotas - estava em desacordo com a violência aniquiladora do navio negreiro e com virtualmente tudo o que eu já tinha escrito. Inicialmente, pensei que queria representar as afiliações rompidas e refeitas no oco do navio negreiro, imaginando as duas garotas como amigas, dando-as uma à outra. Mas no final fui forçada a admitir que queria me consolar e escapar do porão dos escravos com uma visão de algo diferente dos corpos de duas garotas se assentando no fundo do Atlântico.

No fim, eu não podia dizer mais sobre Vênus do que tinha dito sobre sua amiga: "Não tenho certeza se é possível resgatar uma existência a partir de um punhado de palavras: o suposto assassinato de uma garota negra." 43

Eu não podia mudar coisa alguma: “A garota 'nunca terá qualquer existência fora do domicílio precário das palavras' que permitiu que ela fosse assassinada." 44

Eu não poderia ter chegado a outra conclusão. Então era melhor deixá-las como eu as tinha encontrado. Duas garotas, sozinhas.

\section{A reprise}

Escolhi não contar uma história sobre Vênus porque fazer isso teria significado ultrapassar as fronteiras do arquivo. A História se compromete a ser fiel aos limites do fato, da evidência e do arquivo, ainda que tais certezas mortas sejam produzidas pelo terror. Eu queria escrever um romance que excedesse as

\footnotetext{
43 Hartman, Lose Your Mother, 137.

44 Ibid.
} 
ficções da história - os rumores, escândalos, mentiras, evidências inventadas, confissões fabricadas, fatos voláteis, metáforas impossíveis, eventos casuais e fantasias que constituem o arquivo e determinam o que pode ser dito sobre o passado. Eu desejava escrever uma nova história, que não fosse limitada pelos constrangimentos dos documentos legais e fosse além da reiteração e das transposições que constituíram minha estratégia para desordenar e transgredir os protocolos do arquivo e a autoridade de suas afirmações e que me permitiram aumentar e intensificar suas ficções. Encontrar um modo estético apropriado ou adequado para retratar as vidas dessas duas garotas, decidir como dispor as linhas na página, permitir que o rastro narrativo seja reencaminhado ou quebrado pelos sons da memória, os lamentos e prantos e cânticos fúnebres desatados no convés, e tentar perturbar as disposições do poder ao imaginar Vênus e sua amiga fora dos termos de declarações e julgamentos que as baniram da categoria do humano e decretaram que suas vidas eram descartáveis ${ }^{45}$ - tudo isso estava além do que podia ser pensado dentro dos parâmetros da História.

0 romance de resistência que fracassei em narrar e o evento de amor que me recusei a descrever levantam questões importantes sobre o que significa pensar historicamente sobre assuntos ainda contestados no presente e sobre a vida erradicada pelos protocolos de disciplinas intelectuais. 0 que é necessário para imaginar um estado livre ou para contar uma história impossível? É preciso que a poética de um estado livre antecipe seu acontecimento e imagine a vida após o homem, em vez de esperar pelo momento sempre retrocedente do Jubileu? É preciso que o futuro da abolição seja performado primeiro na folha de papel? Ao retirar-me diante da história dessas duas garotas, será que eu estava sustentando as regras da corporação histórica e as "certezas manufaturadas" de seus assassinos e, ao fazê-lo, eu não tinha selado seu destino? ${ }^{46}$ Não tinha também eu relegado as

45 Ver Sylvia Wynter, "Unsettling the Coloniality of Being/Power/Truth/Freedom," CR: The New Centennial Review 3, no. 3 (2003): 257-337.

${ }^{46}$ Stephan Palmié, Wizards and Scientists: Explorations in Afro-Cuban Modernity and Tradition (Durham: Duke University Press, 2002), 94. Ver também Michel-Rolph Trouillot, Silencing the Past (Boston: Beacon Press, 1997). 
duas ao esquecimento? No final das contas, não era melhor deixá-las como as encontrei?

\section{Uma história de fracasso}

Se não é possível desfazer a violência que inaugura o escasso registro da vida de uma garota ou remediar seu anonimato com um nome ou traduzir a fala da mercadoria, então com que finalidade contamos tais histórias? Como e por que escrevemos uma História de violência? Por que revisitar o acontecimento ou o nãoacontecimento da morte de uma garota?

0 arquivo da escravidão repousa sobre uma violência fundadora. Essa violência determina, regula e organiza os tipos de afirmações que podem ser formuladas sobre a escravidão e também cria sujeitos e objetos de poder. ${ }^{47} \mathrm{O}$ arquivo não fornece um relato exaustivo da vida da garota, mas cataloga as afirmações que autorizaram sua morte. Todo o resto é uma espécie de ficção: donzela vivaz, vadia carrancuda, Vênus, garota. A economia do roubo e o poder sobre a vida, que definiram o tráfico negreiro, fabricaram mercadorias e cadáveres. Mas carga, massas inertes e coisas não se prestam à representação, ao menos não facilmente?

Em Lose Your Mother tentei colocar em primeiro plano a experiência das pessoas escravizadas, traçando o itinerário de um desaparecimento e narrando histórias que são impossíveis de contar. O objetivo era expor e explorar a incomensurabilidade entre a experiência das pessoas escravizadas e as ficções da História, ou seja, as exigências da narrativa, a substância de temas e enredos e fins.

E como se conta histórias impossíveis? Histórias sobre garotas com nomes que deformam e desfiguram, sobre as palavras trocadas entre companheiras de navio que nunca adquiriram qualquer reconhecimento diante da lei e que não foram registradas no arquivo, sobre os apelos, preces e segredos nunca proferidos, porque não havia ninguém para recebê-los? A comunicação furtiva que pode ter se passado entre duas garotas, mas que ninguém da tripulação observou ou relatou,

47 Michel Foucault, A arqueologia do saber. $7^{\mathfrak{a}}$ ed. Tradução Luiz Felipe Baeta Neves. Rio de Janeiro: Forense Universitária, 2008, p. 145-147. 
afirma o que já sabemos ser verdade: o arquivo é inseparável do jogo de poder que assassinou Vênus e sua companheira de navio e que exonerou o capitão. E esse conhecimento não nos aproxima de uma compreensão das vidas de duas garotas cativas ou da violência que as destruiu e nomeou a ruína: Vênus. Nem pode explicar por que razão, nesta data tardia, ainda queremos escrever histórias sobre elas.

É possível exceder ou negociar os limites constitutivos do arquivo? Ao propor uma série de argumentos especulativos e ao explorar as capacidades do subjuntivo (um modo gramatical que expressa dúvidas, desejos e possibilidades), ao moldar uma narrativa, que se baseia na pesquisa de arquivo, e com isso quero dizer uma leitura crítica do arquivo que mimetiza as dimensões figurativas da História, eu pretendia tanto contar uma história impossível quanto amplificar a impossibilidade de que seja contada. A temporalidade condicional do "que poderia ter sido", segundo Lisa Lowe, "simboliza adequadamente o espaço de um tipo diferente de pensamento, um espaço de atenção produtiva à cena da perda, um pensamento com atenção dupla, que procura abranger os objetos e métodos positivos da História e da ciência social e, simultaneamente, as questões ausentes, emaranhadas e indisponíveis pelos seus métodos".48

A intenção aqui não é tão miraculosa como recuperar as vidas das pessoas escravizadas ou redimir os mortos, mas em vez disso trabalhar para pintar o quadro mais completo possível das vidas de cativos e cativas. Este gesto duplo pode ser descrito como um esforço contra os limites do arquivo para escrever uma História cultural do cativeiro e, ao mesmo tempo, uma encenação da impossibilidade de representar as vidas dos cativos e cativas precisamente por meio do processo de narração.

O método que guia essa prática de escrita é melhor descrito como fabulação crítica. "Fábula" denota os elementos básicos da história, os blocos de construção da narrativa. Uma fábula, de acordo com Mieke Bal, é "uma série de eventos relacionados lógica e cronologicamente que são causados e Geographies of Intimacy in North American History (Durham: Duke University Press, 2006), 208. 
experimentados por atores. Um evento é uma transição de um estado a outro. Atores são agentes que realizam ações. (Não são necessariamente humanos.) Agir é causar ou experimentar um evento." 49

Jogando com os elementos básicos da história e rearranjando-os, reapresentando a sequência de eventos em histórias divergentes e de pontos de vista em disputa, eu tentei comprometer o status do evento, deslocar o relato preestabelecido ou autorizado e imaginar o que poderia ter acontecido ou poderia ter sido dito ou poderia ter sido feito. Lançando em crise "o que aconteceu quando" e explorando a "transparência das fontes" como ficções da História, eu queria tornar visível a produção de vidas descartáveis (no tráfico atlântico de escravos e também na disciplina da História), descrever "a resistência do objeto" ${ }^{50}$, mesmo que por apenas imaginá-lo primeiro, e escutar os murmúrios e profanações e gritos da mercadoria. Aplainando os níveis do discurso narrativo e confundindo narradora e falantes, eu esperava iluminar o caráter contestado da História, narrativa, evento e fato, derrubar a hierarquia do discurso e submergir a fala autorizada no choque de vozes. O resultado desse método é uma "narrativa recombinante", que "enlaça os fios" de relatos incomensuráveis e que tece presente, passado e futuro, recontando a história da garota e narrando o tempo da escravidão como o nosso presente..$^{51}$

A contenção narrativa, a recusa em preencher as lacunas e dar fechamento, é uma exigência desse método, assim como o imperativo de respeitar o ruído negro - os berros, os gemidos, o sem sentido e a opacidade, que sempre excedem a legibilidade e a lei, e que insinuam e encarnam aspirações que são desvairadamente utópicas, abandonadas pelo capitalismo e antitéticas ao seu concomitante discurso do Homem. ${ }^{52}$

A intenção dessa prática não é dar voz ao escravo, mas antes imaginar o que não pode ser verificado, um domínio de experiência que está situado entre

49 Mieke Bal, Narratology: Introduction to the Theory of Narrative (Toronto: University of Toronto Press, 1997), 7.

50 Moten, In the Break, 14.

51 Tomo emprestada a noção de narrativa recombinante de Stan Douglass, mas a ideia me foi apresentada pelo ensaio não publicado de NourbeSe Philip.

52 Ver Stephen Best e Saidiya Hartman, “Fugitive Justice," Representations, no. 92 (Fall 2005): 9.

Dossiê Crise, Feminismo e Comunicação - https://revistaecopos.eco.ufrj.br/ 
duas zonas de morte - morte social e corporal - e considerar as vidas precárias que são visíveis apenas no momento de seu desaparecimento. É uma escrita impossível que tenta dizer o que resiste a ser dito (uma vez que garotas mortas são incapazes de falar). É uma História de um passado irrecuperável; é uma narrativa do que talvez tivesse sido ou poderia ter sido; é uma História escrita com e contra o arquivo.

Reconhecidamente, a minha própria escrita é incapaz de ultrapassar os limites do dizível ditados pelo arquivo. Ela depende dos registros legais, dos diários dos cirurgiões, dos livros de contabilidade, dos manifestos de carga dos navios e dos diários de bordo, e nesse aspecto ela vacila diante do silêncio do arquivo e reproduz as suas omissões. A violência irreparável do tráfico atlântico de escravos reside precisamente em todas as histórias que não podemos conhecer e que nunca serão recuperadas. Esse obstáculo formidável ou impossibilidade constitutiva define os parâmetros do meu trabalho.

A necessidade de recontar a morte de Vênus é ofuscada pelo fracasso inevitável de qualquer tentativa de representá-la. Penso que esta é uma tensão produtiva que é inevitável ao narrar as vidas das pessoas subalternas, despossuídas e escravizadas. Ao recontar a história do que aconteceu a bordo do Recovery, enfatizei a incomensurabilidade entre os discursos prevalecentes e o evento, amplifiquei a instabilidade e a discrepância do arquivo, desprezei a ilusão realista usual na escrita da História e produzi uma contra-História na intersecção do fictício e do histórico. A contra-História, de acordo com Gallagher e Greenblatt, “opõe-se não apenas às narrativas dominantes, mas também aos modos de pensamento histórico e métodos de pesquisa prevalecentes." 53 Entretanto, a História dos projetos contra-Históricos negros é uma história de fracasso, precisamente porque tais relatos nunca foram capazes de se instalarem como História, mas são antes narrativas insurgentes, perturbadoras, que são marginalizadas e descarrilhadas antes sequer de ganhar pé.

53 Catherine Gallagher e Stephen Greenblatt, “Counter-History and the Anecdote," in Practicing New Historicism (Chicago: University of Chicago, 2001), 52. 
Se essa história de Vênus tem algum valor, este consiste em iluminar o modo como nossa era está presa à dela. Uma relação que outros podem descrever como um tipo de melancolia, mas que prefiro descrever como a sobrevida da propriedade, quero dizer: o detrito de vidas às quais ainda precisamos atentar, um passado que ainda não passou e um estado de emergência contínuo em que a vida negra permanece em perigo.

Por essas razões, escolhi me engajar com um conjunto de dilemas sobre a representação, a violência e a morte social, sem usar a forma de um discurso metahistórico, mas performando os limites de escrever a História por meio do ato de narração. Fiz isso principalmente porque (1) minha própria narrativa não opera fora da economia de afirmações que ela submete à crítica; e (2) aquelas existências relegadas ao não histórico ou consideradas descartáveis exercem uma reivindicação sobre o presente e exigem que imaginemos um futuro no qual a sobrevida da escravidão tenha terminado. A necessidade de tentar representar o que não podemos, em vez de conduzir ao pessimismo ou desespero, deve ser acolhida como a impossibilidade que condiciona nosso conhecimento do passado e anima nosso desejo por um futuro liberto.

Meu esforço para reconstruir o passado é, também, uma tentativa de descrever obliquamente as formas de violências autorizadas no presente, isto é, as formas de morte desencadeadas em nome de liberdade, segurança, civilização e Deus/o bem. A narrativa é central para esse esforço por causa da "relação explícita ou implicada que ela estabelece entre passado, presentes e futuros." ${ }^{54}$ Lutar com a reivindicação da garota sobre o presente é uma forma de nomear nosso tempo, pensar nosso presente e visualizar o passado que o criou.

Infelizmente, não descobri uma forma de perturbar o arquivo de modo que possa recordar o conteúdo da vida de uma garota ou revelar uma imagem mais verdadeira, nem consegui arrombar o livro morto, que selou o estatuto dela como mercadoria. A coleção aleatória de detalhes dos quais fiz uso são as mesmas descrições, citações literais e transcrições de julgamentos que a destinaram à

54 David Scott, Conscripts of Modernity: The Tragedy of Colonial Enlightenment (Durham: Duke University Press, 2004), 7.

Dossiê Crise, Feminismo e Comunicação - https://revistaecopos.eco.ufrj.br/ 
morte e tornaram o assassinato "não muito notado", ao menos de acordo com o cirurgião. ${ }^{55}$ A promiscuidade do arquivo gera uma ampla variedade de leituras, mas nenhuma que seja capaz de ressuscitar a garota.

Meu relato replica a própria ordem de violência contra a qual ele escreve, colocando ainda mais uma demanda sobre a garota, exigindo que sua vida se torne útil ou instrutiva, ao encontrar nela uma lição para nosso futuro ou uma esperança para a História. Nós sabemos muito bem. É tarde demais para que os relatos de morte previnam outras mortes; e é cedo demais para tais cenas de morte interromperem outros crimes. Mas enquanto isso, no espaço do intervalo, entre tarde demais e cedo demais, entre o não mais e o ainda não, nossas vidas são contemporâneas com a da garota no projeto ainda incompleto da liberdade. Enquanto isso, é claro que a vida dela e as nossas estão em jogo.

Então o que se faz enquanto isso? Quais são as histórias que se contam em tempos sombrios? Como uma narrativa de derrota pode possibilitar um lugar para os vivos ou imaginar um futuro alternativo? Michel de Certeau nota que há pelo menos dois modos pelos quais a operação historiográfica pode fabricar um lugar para os vivos: um é atentar para o passado e recrutá-lo em nome dos vivos, estabelecendo quem somos em relação a quem fomos; e o segundo envolve interrogar a produção do nosso conhecimento sobre o passado. ${ }^{56}$ Nas linhas esboçadas por de Certeau, Kindred, de Octavia Butler, oferece um modelo para uma prática. $^{57}$ Quando Dana, a protagonista da ficção especulativa de Butler, viaja do século XX para os anos 1820 para encontrar sua ancestral escravizada, ela descobre, para sua surpresa, que não é capaz de resgatar sua família ou escapar das relações emaranhadas de violência e dominação; em vez disso, acaba aceitando que elas tornaram sua própria existência possível. Com isso em mente, devemos suportar o que não pode ser suportado: a imagem de Vênus acorrentada.

55 Trial of Captain John Kimber, for the Murder of a Negro Girl, 14; Trial of Captain John Kimber for the Supposed Murder of an African Girl, 20. 0 cirurgião testemunhou que castigos brutais a bordo dos navios de escravos eram usuais.

56 Michel de Certeau, The Writing of History (New York: Columbia University Press, 1992). [DE CERTEAU, Michel. A escrita da História. Tradução Maria de Lourdes Menezes. Rio de Janeiro: Forense Universitária, 1982.]

57 Octavia Butler, Kindred (Boston: Beacon Press, 2002). [BUTLER, Octavia. Kindred - Laços de Sangue. Tradução Carolina Caires Coelho. São Paulo: Editora Morro Branco, 2017.]

\section{Dossiê Crise, Feminismo e Comunicação - https://revistaecopos.eco.ufrj.br/}


Começamos a história de novo, como sempre, na esteira de seu desaparecimento e com a esperança desvairada de que nossos esforços possam devolvê-la ao mundo. A conjunção de esperança e derrota define esse trabalho e deixa em aberto seu resultado. A tarefa de escrever o impossível (não o fantasioso ou o utópico, mas "histórias tornadas irreais e fantásticas"58) tem como prérequisitos o acolhimento ao provável fracasso e a prontidão para aceitar o caráter contínuo, inacabado e provisório desse esforço, particularmente quando as disposições do poder ocluem o próprio objeto que desejamos resgatar. ${ }^{59}$ Como Dana, nós também emergimos do encontro com um sentido de incompletude e com o reconhecimento de que alguma parte de nós [the self] está faltando como consequência desse engajamento.

58 Palmié, Wizards and Scientists, 97.

59 Slavoj Žižek descreveu isso como uma prática da resignação entusiasmada. "Entusiasmo ao indicar a experiência do objeto por meio do próprio fracasso de sua representação adequada. Entusiasmo e resignação não são assim dois momentos opostos: é a própria 'resignação', isto é, a experiência de uma certa impossibilidade, que incita o entusiasmo." "Beyond Discourse-Analysis," in Ernesto Laclau, ed., New Reflections on the Revolution of Our Time (New York: Verso, 1990), 25960. 